\title{
Water Quality and Financial Analysis of a System Combining Rainwater and Greywater in a House
}

\author{
Gustavo Rosa and Enedir Ghisi *(D) \\ Laboratory of Energy Efficiency in Buildings, Department of Civil Engineering, Federal University of Santa \\ Catarina, Florianópolis 88040-900, SC, Brazil; gustavo_gcr@hotmail.com \\ * Correspondence: enedir.ghisi@ufsc.br; Tel.: +55-48-3721-2115; Fax: +55-48-3721-5191
}

check for updates

Citation: Rosa, G.; Ghisi, E. Water Quality and Financial Analysis of a System Combining Rainwater and Greywater in a House. Water 2021, 13, 930.

https: / /doi.org/10.3390/w13070930

Academic Editor:

Chicgoua Noubactep

Received: 12 February 2021

Accepted: 23 March 2021

Published: 29 March 2021

Publisher's Note: MDPI stays neutral with regard to jurisdictional claims in published maps and institutional affiliations.

Copyright: (C) 2021 by the authors. Licensee MDPI, Basel, Switzerland. This article is an open access article distributed under the terms and conditions of the Creative Commons Attribution (CC BY) license (https:/ / creativecommons.org/licenses/by/ $4.0 /)$.

\begin{abstract}
This study aimed to evaluate the installation of a system that combines rainwater to wash clothes and greywater to flush toilets in a house located in Florianópolis, southern Brazil. The evaluation consisted of determining the potable water savings, performing a financial analysis, and verifying the possibility of using rainwater and reusing greywater according to the local legislation. The reduction in potable water consumption was determined by comparing the monthly water and sewage bill, before and after installing the system, combining rainwater and greywater. The financial analysis was performed considering the financial benefits, operational costs, costs for installing the system, and local water tariffs. After installing the system, there was a decrease of $38.0 \%$ in the monthly potable water consumption, which represents a decrease of $7.00 \mathrm{~m}^{3}$ in the monthly potable water consumption. The payback periods for the old and new water tariffs were equivalent to, respectively, ten years and seven months, and eight years and five months. Both rainwater and greywater had parameters with concentrations higher than the limits established by the legislation. Therefore, the rainwater had to go through a device for discarding the first flush and needed disinfection; and the greywater needed to go through a treatment process. The results indicated that the system combining rainwater and greywater shows significant potential for potable water savings, which can be a good alternative to the preservation of potable water resources. It is important to note that current studies on rainwater use and greywater reuse are mainly related to non-potable purposes, but it was shown herein that rainwater can be used for washing clothes.
\end{abstract}

Keywords: water consumption; water resources; rainwater; greywater; potable water savings; financial analysis

\section{Introduction}

Over the last decade, a shortage of potable water resources has been observed, which is due to the decline in quantity and quality of water bodies [1]. This shortage has promoted actions aiming at the preservation of water resources with appropriate quantity and quality. According to [2], there has been an increase in practices of rational use of water. The purpose of using combined water systems in households is to save water [3]. Nowadays, studies on combined systems are mainly related to the use and reuse of water for nonpotable purposes. Rainwater and greywater have the potential to meet a significant part of the water consumption in toilet flushing, garden irrigation, and car washing [4]. However, it is necessary to study the water quality of rainwater and greywater for washing clothes, for example. The use of rainwater leads to a reduction of potable water consumption, a decrease in the water bill, and a reduction in the volume of rainwater directed to drainage systems [5]. Rainwater use can transform hazards, such as floods, into sources of water for certain applications [6]. There has been an increase in studies about greywater reuse related to ecological practices. In a building, greywater comes from showers, bathtubs, washbasins, and washing machines [7].

There are two main ways of using rainwater and reusing greywater in a building: combined systems and hybrid systems. In hybrid systems, before the treatment process, 
rainwater and greywater are stored in the same tank [3]. It is important to note that this study aims to evaluate the combined systems, in which rainwater and greywater are treated separately, without a combination of flows.

The combined systems aim to overcome possible disadvantages observed on the rainwater use [3]. The following problems can be found: low precipitation, buildings located on small water catchment areas, and small tank capacities. Low rainfall levels influence the efficiency of a rainwater use system directly. The utilisation of a system combining rainwater and greywater might offset irregular precipitation over the year because the greywater is generated regardless of the weather conditions [4].

It is important to note studies related to the aspects of the quality and quantity of the combined systems. On the quantity aspects, the reviews are associated with reducing the potable water consumption in households. On the other hand, the quality is related to the safety of the user, in which the quality parameters must comply with the limits defined by the relevant legislation indicated for the use of rainwater and the reuse of greywater. Studies on financial analysis are also relevant. The cost-benefit and payback analysis are important for the decision-making on the part of the household's owner regarding the installation of the system [5].

Currently, studies on rainwater use and greywater reuse are mainly related to nonpotable purposes. Therefore, it is important to note the relevance of the new studies and technologies related to rainwater use and greywater reuse for potable purposes. Rainwater, in this study, was used for washing clothes, which is considered a potable purpose. It is important to note that studies related to the rational use of water are relevant, aiming to maintain healthy water bodies, ensuring aspects of quality and quantity for the population [8].

The objective of this study was to evaluate the installation of a system that combines rainwater to wash clothes and greywater to flush toilets in a house located in Florianópolis, southern Brazil. Water quality, potable water savings, and financial analysis were performed.

\section{Materials and Methods}

This study was performed in a two- storey single-family house located in the city of Florianópolis. The house has a catchment area of approximately $120 \mathrm{~m}^{2}$. There are the following water fixtures: three toilets, three washbasins, two showers, one kitchen sink, one washing machine, one laundry trough, and one garden tap. The combined system, in this study, consists of using rainwater to wash clothes and reusing the effluent to flush toilets. Figure 1 shows the schematic of the system.

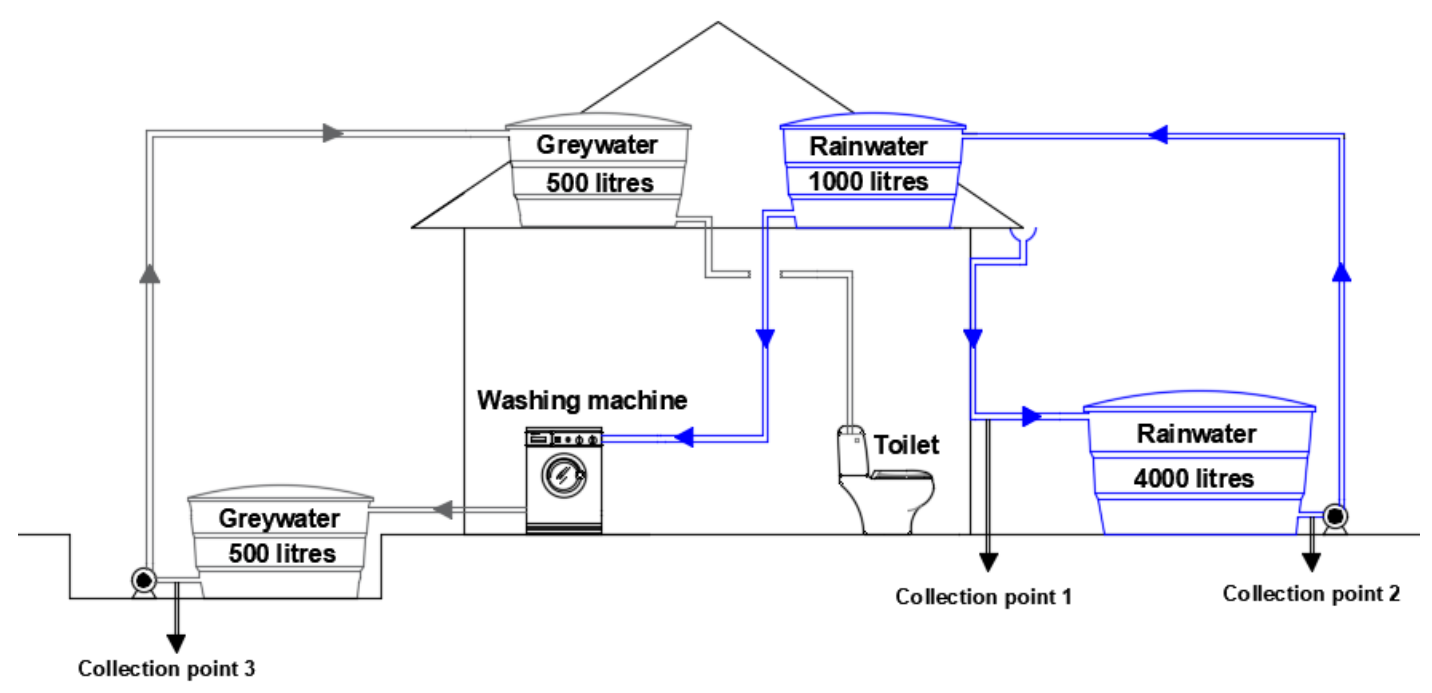

Figure 1. Schematic of the system combining rainwater use and greywater reuse. 
The rainwater was stored in a ground-level tank. Before storage, rainwater passed through a device for the first flush to remove coarse solids and other debris. The Brazilian Standard NBR 15527 [9] recommends the disposal of two millimetres for the first flush, which was adopted in this study. The rainwater was then pumped to an upper tank and used for washing clothes. The washing machine effluent, i.e., greywater, was stored in another tank and reused to flush toilets.

The evaluation of a system that combines rainwater for washing clothes and greywater for flushing toilets consisted of the following steps: quantity analysis, quality analysis and financial analysis. The quantity analysis consisted of verifying the reduction of potable water consumption in the house after installing the combined system. The quality analysis aimed to verify the possibility of using rainwater for washing clothes and greywater for flushing toilets. The financial analysis aimed to assess the financial feasibility of the combined system, considering the net present value, internal rate of return, and payback. The following factors were considered: initial investment outlay, determination of the financial benefits, and operational costs. Figure 2 shows the flowchart of the method used herein; and details about each step of the method can be found in the sections below.

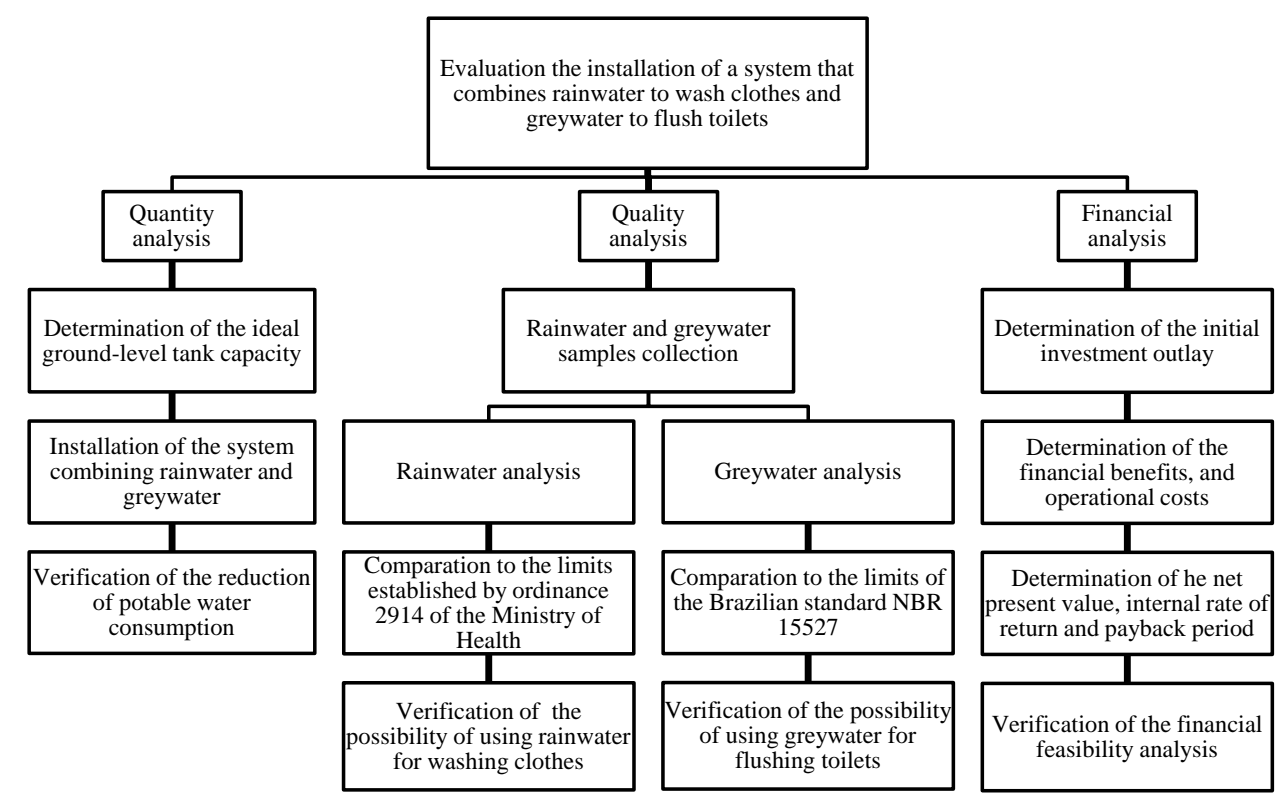

Figure 2. Flowchart of the method.

\subsection{The Ground-Level Tank Capacity}

Netuno version 4 was the computer programme used to determine the ideal groundlevel tank capacity. The main outputs of the programme are: potential for potable water savings by using rainwater, ideal tank capacity, overflowing volume of rainwater, and financial analysis [10]. There are other methods available to size rainwater tanks; details about them can be found in reference [11].

Local daily rainfall over ten years (2002-2011) was used as input data to run the simulations. The average monthly cost of potable water was obtained from the water bill provided by the house owners in 2017.

For the upper rainwater tank, a capacity equal to $1000 \mathrm{~L}$ was used, there being water pumping when the amount of rainwater in the tank was below $10.0 \%$. For the ground-level rainwater tank capacity, simulations ranging from 1000 to 50,000 L at $1000 \mathrm{~L}$ interval were performed. The ideal ground-level tank capacity was chosen when there was a difference of three per cent per cubic meter between the potentials for potable water savings. Table 1 shows the input data used to perform computer simulations using Netuno. 
Table 1. Input data used to perform computer simulations using Netuno.

\begin{tabular}{cc}
\hline Input Data & Measurement Unit \\
\hline First flush & $2 \mathrm{~mm}$ \\
Catchment area & $120 \mathrm{~m}^{2}$ \\
Average water demand over 2017 & $148 \mathrm{~L} \mathrm{per} \mathrm{capita/day}$ \\
Number of people living in the house & 4 \\
Rainwater demand (percentage of the total & Water end-use for the washing machine $44.0 \%$ \\
water demand to be replaced with rainwater) & $\pm 5.0 \%$ \\
Run-off coefficient & 0.90 \\
Upper rainwater tank capacity & $1000 \mathrm{~L}$ \\
Ground-level rainwater tank capacity & $1000-50,000 \mathrm{~L} \mathrm{(at} \mathrm{1000} \mathrm{L} \mathrm{interval)}$ \\
\hline
\end{tabular}

\subsection{Potable Water Savings}

The water consumption before and after the installation of the system combining rainwater and greywater was compared. Based on the monthly water/sewage bill provided by the house owners, the water consumption was monitored for twelve months. The combined system was installed in January 2018. The potable water savings were calculated using Equation (1) and the percentage reduction of water consumption in the house was calculated using Equation (2).

$$
e=C_{0}-C_{i}
$$

where: $e$ is the monthly potable water savings $\left(\mathrm{m}^{3}\right) ; C_{0}$ is the average monthly water consumption before the installation of the system combining rainwater and greywater $\left(\mathrm{m}^{3}\right)$; $C_{i}$ is the average monthly water consumption after the installation of the system combining rainwater and greywater $\left(\mathrm{m}^{3}\right)$.

$$
r_{p}=\left(\frac{C_{o}-C_{i}}{C_{o}}\right)
$$

where: $r_{p}$ is the percentage reduction of water consumption in the house (\%); $C_{0}$ is the average monthly water consumption before the installation of the system combining rainwater and greywater $\left(\mathrm{m}^{3}\right) ; C_{i}$ is the average monthly water consumption after the installation of the system combining rainwater and greywater $\left(\mathrm{m}^{3}\right)$.

The water consumption per capita was calculated in a way similar to that presented above.

\subsection{Water Quality}

The water quality analysis was carried out to verify the possibility of using rainwater to wash clothes and greywater to flush toilets, complying with the limits established by the legislation. From April 2018 to January 2019, twelve analyses were performed for each of the following collection points: rainwater from the catchment area, rainwater stored in the ground-level tank, and greywater stored in the corresponding tank. The samples were only collected when the volume of rainfall was considered sufficient to characterise the water quality parameters. This section presents the methods used to determine parameters for rainwater and greywater, as well as to verify the parameters according to the limits established by the legislation.

\subsubsection{Rainwater}

It is important to note that the rainwater stored in the ground-level tank passed through a device for the first flush, and there was disinfection using sodium hypochlorite.

For the rainwater from the catchment area, the following parameters were analysed: turbidity, apparent colour, $\mathrm{pH}$, hardness, thermotolerant coliforms, and total dissolved solids. For the rainwater stored in the ground-level tank, free residual chlorine was also analysed.

The results found were compared to the limits established by ordinance 2914 of the Ministry of Health [12]. This ordinance provides for the water quality for human consumption. Table 2 shows the limits established by the legislation, as well as the methods 
of analysis. The parameters were analysed following the recommendations of the Standard Methods for the Water and Wastewater [13].

Table 2. Methods of analysis and limits established by the local legislation for rainwater.

\begin{tabular}{cccc}
\hline Parameter & Method & Limit Established & Unit \\
\hline Free residual chlorine & EPA 330.5, APHA 450-C12 G & Between 0.20 and 5.00 mg/L & $\mathrm{mg} \mathrm{Cl} / \mathrm{L}$ \\
Thermotolerant coliforms & $9222 \mathrm{~A}, 9222 \mathrm{~B}, 9222$ & Absence & UFC/100 ml \\
Apparent colour & $2120 \mathrm{C}$ & 15.00 & $\mathrm{mg} \mathrm{Pt}-\mathrm{Co} / \mathrm{L}$ \\
Turbidity & $2130 \mathrm{~B}$ & 5.00 & $\mathrm{NTU}$ \\
Total dissolved solids & $2540 \mathrm{~B}$ & 1000.00 & $\mathrm{mg} / \mathrm{L}$ \\
Hardness & $2340 \mathrm{C}$ & 500.00 & $\mathrm{mg} / \mathrm{L}$ \\
$\mathrm{pH}$ & $4500 \mathrm{H}$ & 6.00 to 9.50 at $25^{\circ} \mathrm{C}$ & - \\
\hline
\end{tabular}

The effects of the independent variables on the collected rainwater were statistically assessed using the Microsoft Excel software (2016) and the statistical tool Data Analysis. The results were analysed by means of analysis of variance at a significance level of $5 \%$.

\subsubsection{Greywater}

As for the greywater from the washing machine, the following parameters were analysed: turbidity, $\mathrm{pH}$, thermotolerant coliforms, and free residual chlorine. The results found were compared to the limits of the Brazilian standard NBR 15527 [9]. The standard provides for the reuse of water for the following non-potable purposes: water cooling systems, flushing toilets and urinals, washing vehicle, washing floors, firefighting, ornamental use (fountains and lakes), and irrigation for landscape purposes. Table 3 shows the limits established by the legislation, as well as the methods of analysis. The parameters were analysed following the recommendations of the Standard Methods for the Water and Wastewater [13].

Table 3. Methods of analysis and limits established by the legislation for greywater.

\begin{tabular}{cccc}
\hline Parameter & Method & Limit & Unit \\
\hline Free residual chlorine & EPA 330.5, APHA 450-C12 G & 0.50 to 2.00 & mg/L \\
Thermotolerant coliforms & $9222 \mathrm{~A}, 9222 \mathrm{~B}, 9222$ & $<200$ & UFC/100 mL \\
Turbidity & $2130 \mathrm{~B}$ & $<5.00$ & NTU \\
$\mathrm{pH}$ & $4500 \mathrm{H}$ & Between 6.00 and 9.00 & - \\
\hline
\end{tabular}

\subsection{Financial Analysis}

The net present value, internal rate of return and payback period for the installation of the system that combines rainwater to wash clothes and greywater to flush toilets were estimated. The financial analysis was performed considering the initial investment outlay, financial benefits, and operational costs. The financial benefit is the reduction in the water/sewage bill due to the potable water savings generated by the installation of the system. The operational costs refer to the additional costs due to electricity consumption originated by the use of the pump, maintenance, and water treatment.

\subsubsection{Initial Investment Outlay}

Costs related to material, equipment, and labour were considered. All unit costs were based on market research. The initial investment for installing the system was calculated using Equation (3).

$$
I_{0}=C_{\text {mat }}+C_{\text {manpower }}
$$

where: $I_{0}$ is the initial investment outlay for the installation of a rainwater use and greywater reuse system $(\mathrm{R} \$) ; C_{\text {mat }}$ are the costs of materials and equipment for the installation of the system ( $R \$) ; C_{\text {manpower }}$ are the labour costs $(R \$)$. 


\subsubsection{Payback Period}

The computer programme Netuno was used to perform the financial feasibility analysis [10]. The financial analysis was performed using the old water tariff (tariffs charged until February 2020) and the new water tariff implemented by the local water company in March 2020. Table 4 shows the tariffs charged until February 2020. It is important to note that if the monthly water consumption was lower than or equal to $10 \mathrm{~m}^{3}$, there was a flat tariff equal to $\mathrm{R} \$ 45.19$. The water company charges $100 \%$ over the water bill on the purpose of funding the harvest and treatment of the effluents produced in the house.

Table 4. Water tariffs charged by the local water company until February 2020.

\begin{tabular}{cc}
\hline Monthly Water Consumption Wc $\left(\mathbf{m}^{3}\right)$ & Water Tariff \\
\hline$W_{c} \leq 10$ & $\mathrm{R} \$ 45.19$ (flat rate) \\
$10<\mathrm{Wc} \leq 25$ & $8.2814 \mathrm{R} \$ / \mathrm{m}^{3}$ \\
$25<\mathrm{Wc} \leq 50$ & $11.6187 \mathrm{R} \$ / \mathrm{m}^{3}$ \\
$\mathrm{Wc}_{\mathrm{C}}>50$ & $13.9229 \mathrm{R} \$ / \mathrm{m}^{3}$ \\
\hline
\end{tabular}

Note: on 12 March 2021, 1 Brazilian Real (R\$) equals US\$ 0.18 and $€ 0.15$.

Table 5 shows the new water tariff, implemented in March 2020. The main change in the new tariff was the end of the flat rate for monthly water consumption lower than or equal to $10 \mathrm{~m}^{3}$. Currently, a Fixed Tariff of Infrastructure Availability (TFDI) is charged, i.e., $\mathrm{R} \$ 29.49$ per month. There is still a charge of $100 \%$ over the water bill on the purpose of funding the harvest and treatment of the effluents produced in the house.

Table 5. New water tariffs charged by the local water company from March 2020 onwards.

\begin{tabular}{|c|c|}
\hline Monthly Water Consumption Wc $\left(\mathrm{m}^{3}\right)$ & Water Tariff $\left(\mathrm{R} \$ / \mathrm{m}^{3}\right)$ \\
\hline $\mathrm{Wc}_{\mathrm{c}} \leq 10$ & 1.9600 \\
\hline $10<\mathrm{Wc} \leq 25$ & 9.1100 \\
\hline $25<W_{c} \leq 50$ & 12.1800 \\
\hline$W_{c}>50$ & 15.3200 \\
\hline
\end{tabular}

In this study, an inflation rate equal to $0.24 \%$ per month was considered, which is equivalent to the inflation rate over 2017 in Brazil (according to Brazil Central Bank). A service life equal to 20 years and a minimum acceptable rate of return equal to $0.60 \%$ per month were taken into account. One also considered readjustments on the water and electricity tariffs every 12 months.

Table 6 shows the input data for the initial investment related to materials and labour. The unit costs were based on local market research (three stores and three labour suppliers).

Table 6. Initial investment related to materials and labour.

\begin{tabular}{cc}
\hline Initials Investments & Costs (R\$) \\
\hline Ground-level tank & 1300.00 \\
Upper tank & 259.00 \\
Labour & 1800.00 \\
Pipes & 692.10 \\
Accessories & 1686.34 \\
\hline
\end{tabular}

Table 7 shows the data on the pump for the financial analysis. The starting time was calculated using Equation (4).

$$
t=\frac{V_{m l r}}{Q_{m b 1}} .
$$

where: $t$ is the time the pump works to pump rainwater from the ground-level tank to the upper tank (h/month); $V_{m l r}$ is the daily water consumption in the washing machine over 
the measurement period (litres); $Q_{m b 1}$ is the operational pumping flow of a $\frac{1}{2} \mathrm{HP}$ pump, available on the manufacturer's guidelines (litres/hour).

Table 7. Pump information for the financial analysis.

\begin{tabular}{cc}
\hline Power (HP) & 0.50 \\
Efficiency (\%) & 80 \\
Flow (litres/hour) & 2160 \\
Starting time (seconds) & 357.15 \\
Cost of each pump (R\$) & 155.00 \\
Electricity tariff for the residential sector & 0.46978 \\
(R\$/kWh) & \\
\hline
\end{tabular}

The computer programme Netuno also allows the input of other operation costs and maintenance costs, which is important for a more accurate financial analysis. Table 8 shows the input data for operation and maintenance costs.

Table 8. Input data for operation and maintenance costs.

\begin{tabular}{cccc}
\hline Operation and Maintenance Costs & Frequency (Months) & Cost Type & Cost (R\$) \\
\hline Cleaning the system & 12 & Fixed & 540.00 \\
Pump & 12 & Fixed & 30.00 \\
Disinfection & 1 & Fixed & 10.00 \\
\hline
\end{tabular}

\subsubsection{Financial Benefit}

The financial benefit due to the system combining rainwater and greywater was calculated using Equation (5).

$$
B=C_{\text {pot }}-C_{\text {comb }}
$$

where: $B$ is the financial benefit due to the system combining rainwater and greywater (R\$/month); $C_{\text {pot }}$ is the average monthly cost of potable water before the installation of the system combining rainwater and greywater ( $R \$ /$ month); $C_{\text {comb }}$ is the average monthly cost of potable water after the installation the system combining rainwater and greywater (R\$/month).

The monthly costs of potable water before and after installing the system combining rainwater and greywater were obtained from the water bills provided by the house owners.

\section{Results and Discussions}

\subsection{Potable Water Savings}

According to a previous study on the water end-uses in the house, the washing of clothes represents $44.4 \%$ of the potable water consumption in the house [14]. Therefore, the rainwater demand considered was $44 \pm 5 \%$ of the total water demand; that is, the simulations were performed considering rainwater demands equal to $39.0 \%, 44.0 \%$, and $49.0 \%$ of the total water demand. Figure 3 shows the corresponding potential for potable water savings as a function of the rainwater tank size. The black dots indicate the ideal tank capacity for each rainwater demand.

A ground-level tank capacity equal to $4000 \mathrm{~L}$ was adopted, as it was the capacity indicated as ideal in the three simulations performed. The upper rainwater tank capacity was chosen as $1000 \mathrm{~L}$. Therefore, $5000 \mathrm{~L}$ were used for rainwater storage. The computer programme Netuno indicates that the installation of a ground-level rainwater tank with a capacity equal to $4000 \mathrm{~L}$ can reduce $39.58 \%$ the potable water consumption in the house. Such a tank capacity would be capable to fully meet the rainwater demand over $88.80 \%$ of the days in the year. 


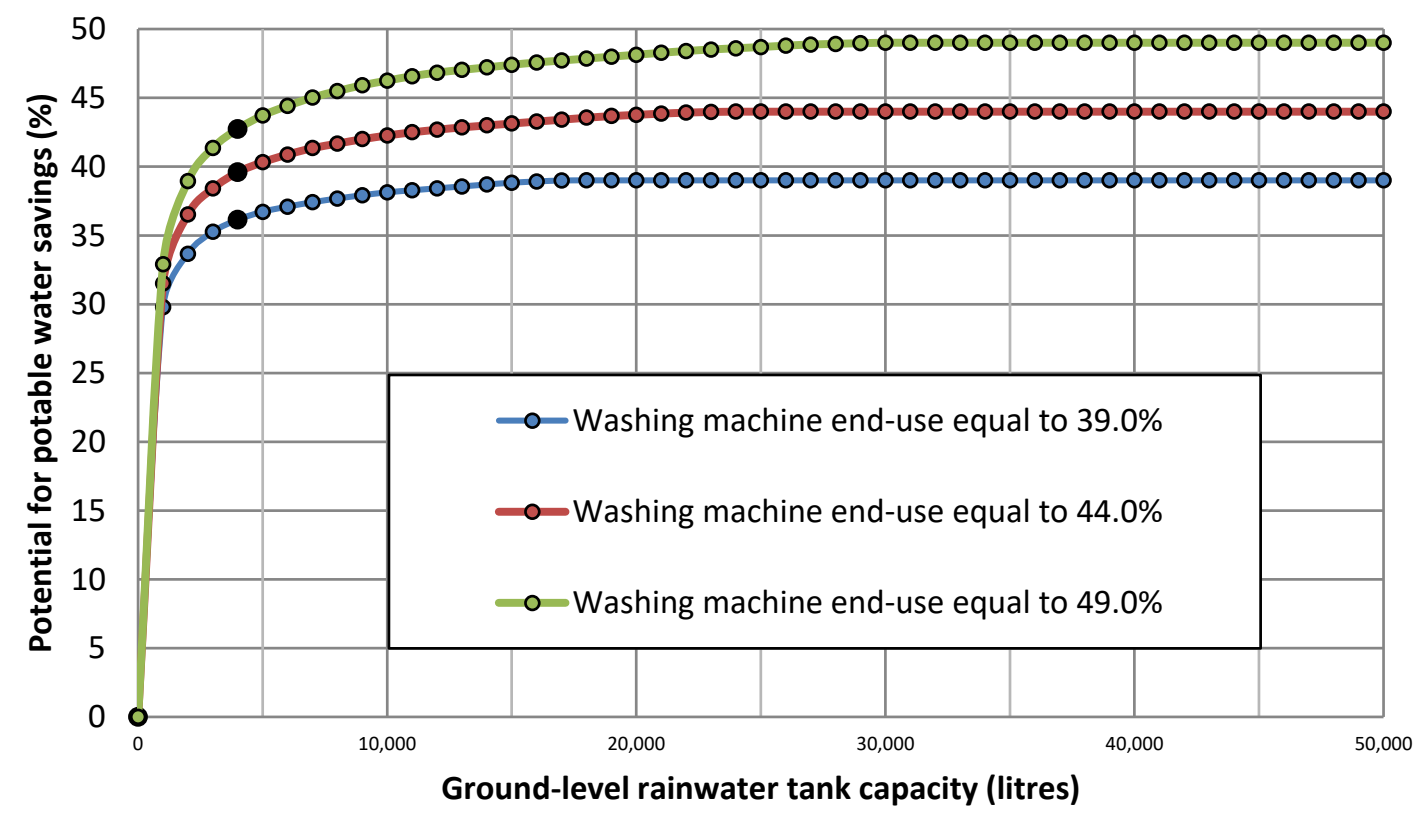

Figure 3. Potential for potable water savings as a function of the rainwater demand and ground-level rainwater tank capacity.

Figure 4 shows the monthly potable water consumption in the house before and after installing the system combining rainwater and greywater.

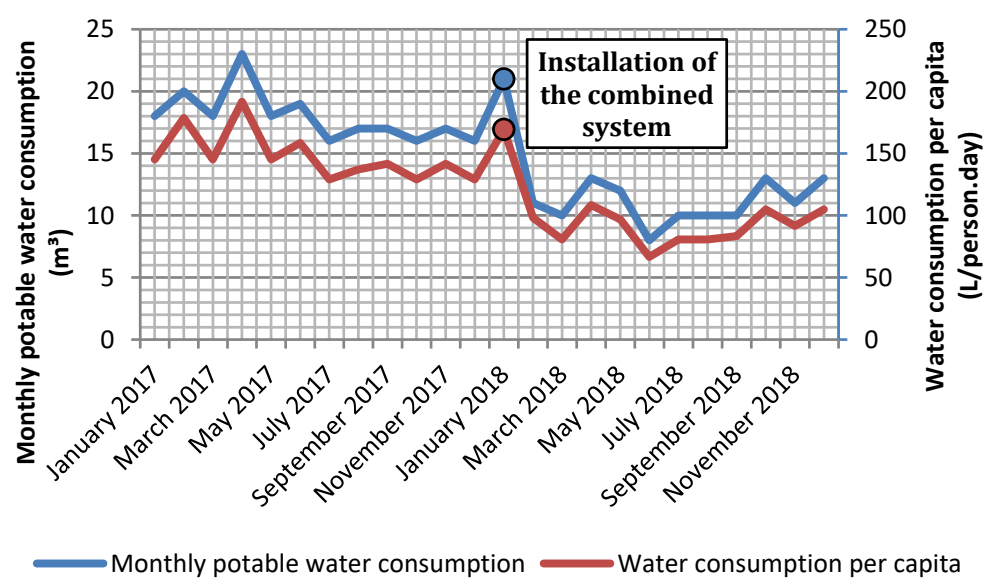

Figure 4. Monthly potable water consumption in the house.

There was a significant reduction in potable water consumption from the beginning of 2018, a period in which the combined system was installed. In the first month, after installing the system, there was an immediate reduction equal to $31.0 \%$ in potable water consumption compared to the last month before the installation of the combined system.

The reduction of monthly potable water consumption ranged from $19.0 \%$ to $58.0 \%$ after the installation of the combined system. The average monthly reduction was $38.0 \%$. There are studies that present results similar to the one found in this study. Muthukumaran et al. [15] obtained savings of $40.0 \%$ in potable water consumption due to the installation of a system combining rainwater and greywater in houses in Australia. Ghisi and Oliveira [16] obtained potential for potable water savings equal to $36.4 \%$ and $33.9 \%$ for two houses located in the city of Palhoça, southern Brazil. In the city of Florianópolis, southern Brazil, it was observed that the installation of a combined system in low-income houses would lead to potable water savings equal to 32.5\% [17]. Moreover, in Florianópolis, Ghisi and Ferreira [18] studied the potential for potable water savings in three multi-family buildings; potential for potable water savings equal to $36.7 \%, 37.9 \%$ and $42.0 \%$ were observed in each 
building. In Colombia, Oviedo-Ocaña et al. [19] obtained potable water savings equal to $44.0 \%$ due to the installation of a combined system in a residential complex.

It is important to note that although there are results that are in line with this study, there is a high range of variation because the use of rainwater is directly associated with rainfall characteristics, potable water demand, catchment area, and tank capacity.

Figure 4 shows that, after the installation of the combined system, the average potable water consumption was $91 \mathrm{~L}$ per capita/day, ranging from 67 to $108 \mathrm{~L}$ per capita/day. According to [20], the average water consumption in Brazil and Santa Catarina is 154 and 149 L per capita/day, respectively.

\subsection{Water Quality Analysis}

Table 9 shows the collection date, air temperature, and weather conditions on the days the water samples were collected. For each date, samples were collected at the three collection points shown previously in Figure 1. The samples were collected after rainy periods, in which there was sufficient rainfall to characterize the sample.

Table 9. Collection date, air temperature, and weather conditions during the water samples collection.

\begin{tabular}{cccc}
\hline Sample & Collection Date & Air Temperature $\left({ }^{\circ} \mathbf{C}\right)$ & Weather \\
\hline 1 & 19 April 2018 & 21.0 & Cloudy \\
2 & 29 May 2018 & 19.5 & Cloudy \\
3 & 21 June 2018 & 18.9 & Sunny \\
4 & 11 July 2018 & 18.5 & Cloudy \\
5 & 30 August 2018 & 17.6 & Rainy \\
6 & 3 September 2018 & 17.9 & Sunny \\
7 & 18 September 2018 & 22.4 & Sunny \\
8 & 26 October 2018 & 22.0 & Sunny \\
9 & 30 October 2018 & 22.4 & Cloudy \\
10 & 29 November 2018 & 23.2 & Cloudy \\
11 & 12 December 2018 & 23.5 & Sunny \\
12 & 9 January 2019 & 33.5 & \\
\hline
\end{tabular}

\subsubsection{Rainwater from the Catchment Area}

The rainwater from the catchment area was analysed and compared to ordinance 2914 of the Ministry of Health [12], in which there are potability parameters for human consumption. Figure 5 shows the turbidity results for the twelve samples from the catchment area. The limit established by ordinance 2914 is 5.00 NTU. Some samples exceeded that limit. That is due to the solid materials in the catchment area. It is important to highlight that after rainy periods, low concentrations of turbidity were observed. According to [21], turbidity, in the form of suspended solids, can serve as a shelter for pathogenic microorganisms, decreasing the efficiency of disinfection. Therefore, before the use of rainwater, a treatment process must be used to reduce or eliminate suspended solids in the water.

Figure 6 shows the apparent colour results for the twelve samples obtained from the catchment area. The upper limit for apparent colour is $15 \mathrm{mg} \mathrm{Pt}-\mathrm{Co} / \mathrm{L}$ [12]. Most of the apparent colour samples exceeded that limit, being directly related to the presence of suspended solids in the collected rainwater. Von Sperling [21] states that colouration above $15.00 \mu \mathrm{C}$ can be detected visually by consumers, who may question its reliability. The presence of apparent colour can create health risks for users. 


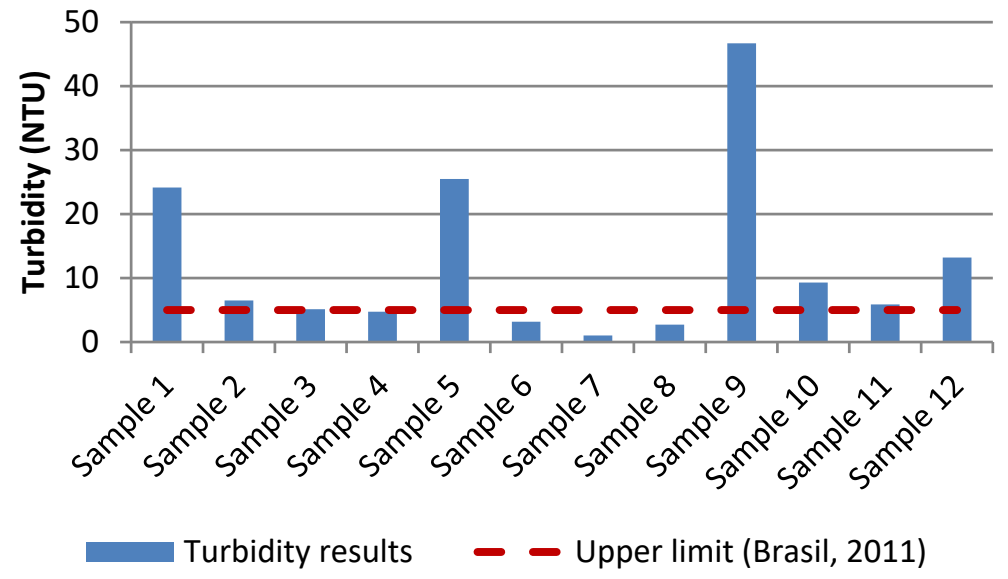

Figure 5. Turbidity of the rainwater from the catchment area.

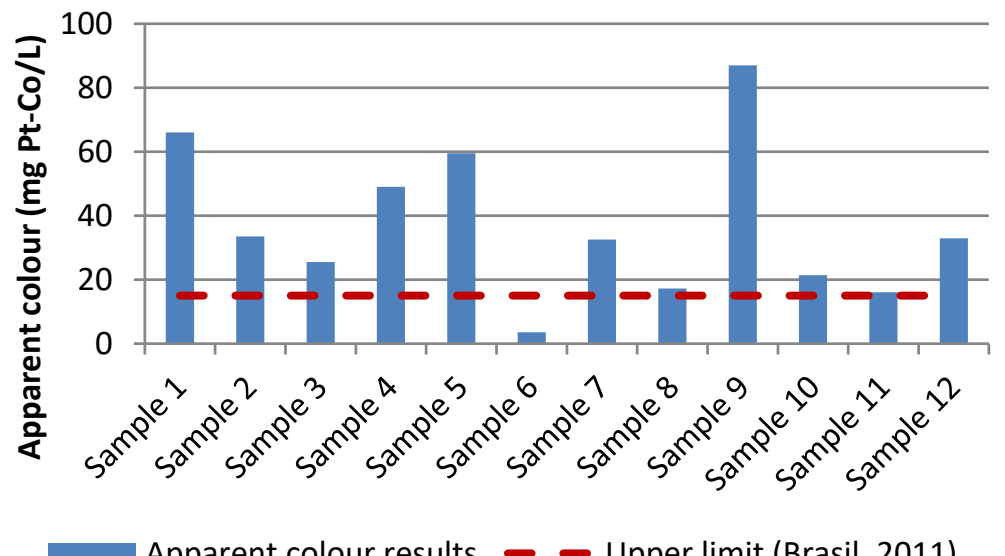

Figure 6. Apparent colour of the rainwater from the catchment area.

The $\mathrm{pH}$ can give acidic or basic characteristics to the water. Such parameter can also generate corrosion in pipes and other parts of the system. Figure 7 shows $\mathrm{pH}$ results for the twelve samples from the catchment area. The lower and upper limits, aiming to guarantee the potability of the water, are 6.00 and 9.50, respectively [12]. Therefore, all samples have a $\mathrm{pH}$ in the range required by the Ministry of Health, indicating the possibility of using rainwater to wash clothes.

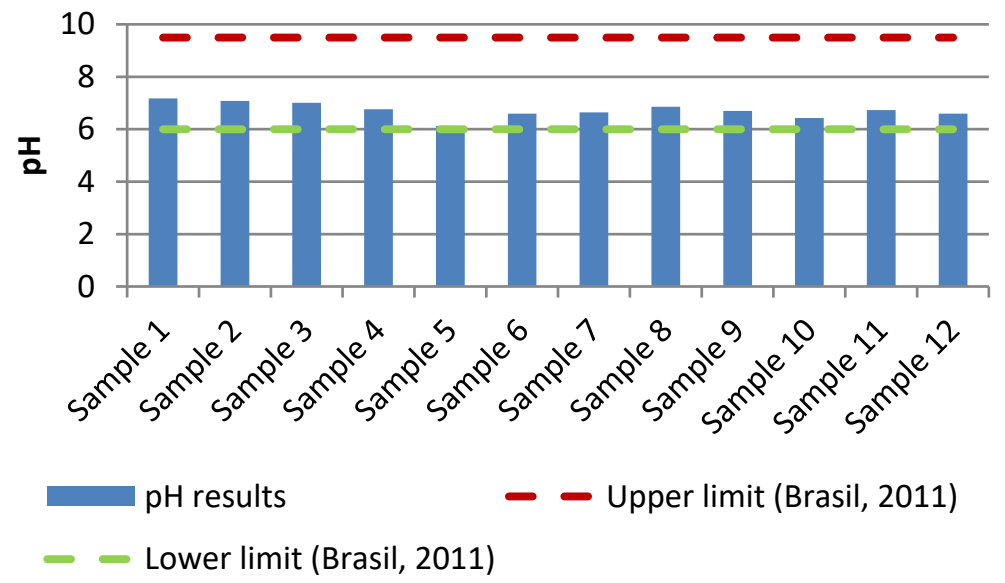

Figure 7. $\mathrm{pH}$ of the rainwater from the catchment area. 
The hardness parameter is directly related to the dissolution of soap in water, that is, the higher the concentration of hardness in the water, the greater the difficulty in washing clothes. Figure 8 shows hardness results for the twelve samples from the catchment area. The limit established by ordinance 2914 [12] is $500 \mathrm{mg} / \mathrm{L}$. In this study, the hardness was much lower than that limit, which indicates again that such rainwater can be used to wash clothes.

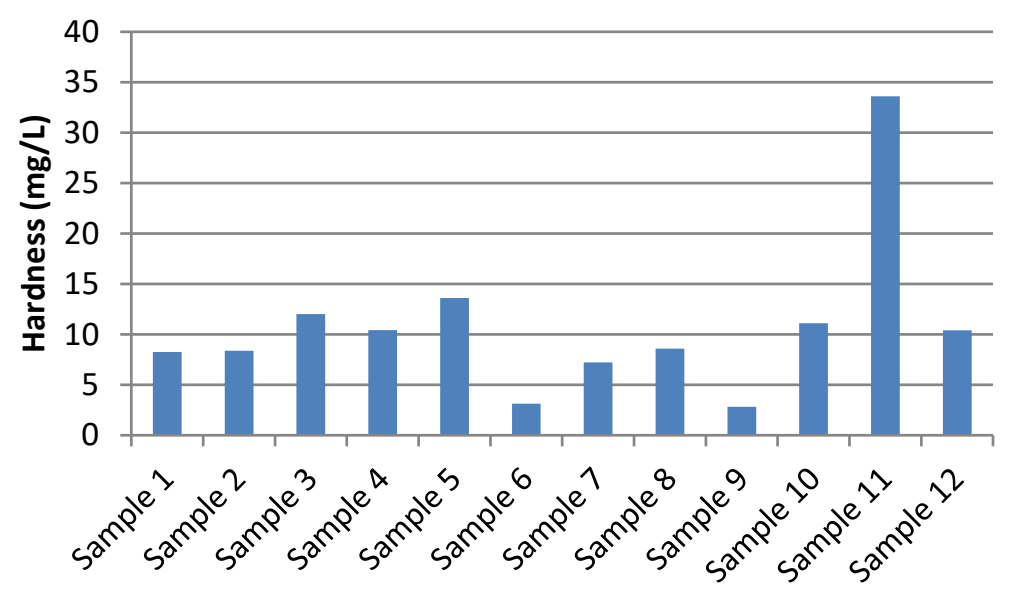

Figure 8. Hardness of the rainwater from the catchment area.

The count of thermotolerant coliforms indicates the presence of fa below the lower limit. It is important ecal coliforms in the water. Figure 9 shows thermotolerant coliforms results for the twelve samples from the catchment area. Ordinance 2914 [12] indicates that there should be no presence of thermotolerant coliforms. However, all samples showed colony-forming units of thermotolerant coliforms. Therefore, considering this parameter, the collected rainwater should not be used to wash clothes unless there is some treatment.

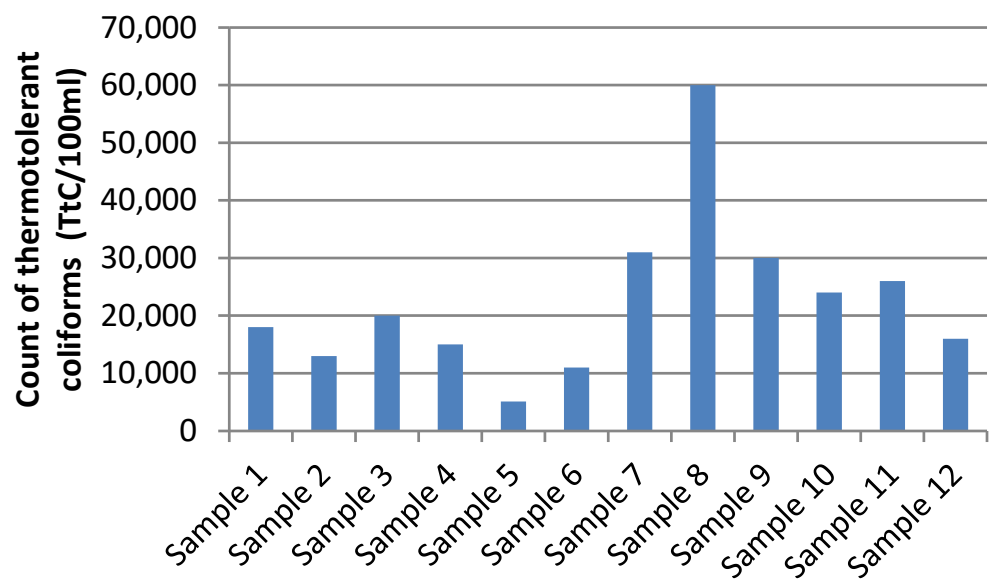

Figure 9. Thermotolerant coliforms in the rainwater from the catchment area.

Figure 10 shows the total dissolved solids results for the twelve samples from the catchment area. The concentration of total dissolved solids should not exceed $1000 \mathrm{mg} / \mathrm{L}$ [12]. All concentrations of the samples analysed meet such limit. 


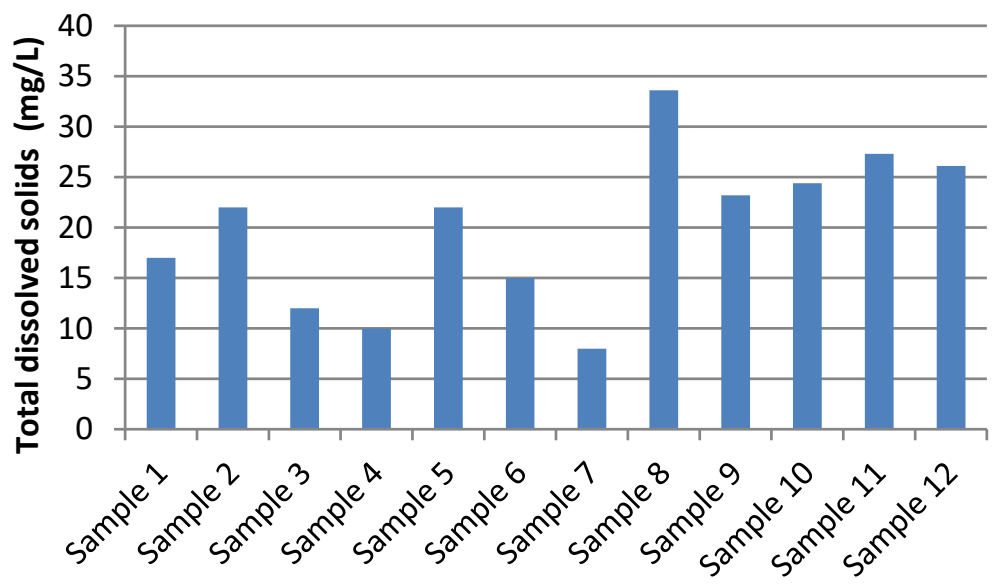

Figure 10. Total dissolved solids in the rainwater from the catchment area.

It was observed that the parameters turbidity, apparent colour and thermotolerant coliforms exceed the limits established by the Ministry of Health, in the ordinance 2914 [12]. Turbidity and apparent colour are directly related to suspended solids in the rainwater from the catchment area. Therefore, aiming to remove suspended solids in the collected rainwater, a device for discarding the first flush was used. The capacity of the device was calculated for a volume equivalent to $2.0 \mathrm{~mm}$ of rain [9]. The device prevents the accumulation of organic matter in the tanks, prevents corrosion in the pipes and reduces the likelihood of damage to the pump [3].

Lee et al. [1] note that leaves and animal droppings are the main factors related to microbial contamination in rainwater catchment systems. Due to the high concentration of thermotolerant coliforms, a disinfection process is necessary, aiming to ensure safety for users. In this study, disinfection was performed using sodium hypochlorite. It is important to note that rainwater must undergo a disinfection process to eliminate bacteria, protozoa and other pathogenic microorganisms.

Following the first-flush and the disinfection using sodium hypochlorite, the rainwater was stored in a tank, aiming to later use for washing clothes. Section 3.2.2 addresses the potability parameters, aiming to verify the possibility of using rainwater for washing clothes.

\subsubsection{Rainwater to Wash Clothes}

The results of the analysis aiming to use rainwater for washing clothes can be seen in Figures A1-A6 shown in Appendix A. The following parameters were analysed: turbidity, apparent colour, thermotolerant coliforms, free residual chlorine, $\mathrm{pH}$, total dissolved solids and hardness. The results were compared to the limits established by the Ministry of Health, ordinance 2914 [12].

By discarding the first-flush, there was a reduction in the concentrations of turbidity and apparent colour. Regarding turbidity, all samples lied within the limit established by the Ministry of Health. The sixth sample of apparent colour exceeded the limit. The reductions would be related to the retention of suspended solids in the device. Tables A1 and A2 in Appendix B show, respectively, that turbidity and apparent colour were significantly influenced by the following independent factors: collection points and collection days. The interactions between them showed $p<0.05$.

After disinfection, no colony-forming units of thermotolerant coliforms were found. The absence of thermotolerant coliforms guarantees the safe use of rainwater to users. It is important to note that the concentration of free residual chlorine should be monitored. The lower and upper limits established by the Ministry of Health are equivalent to, respectively, 0.20 and $5.00 \mathrm{mg} / \mathrm{L}$. The first samples showed concentrations below $0.20 \mathrm{mg} / \mathrm{L}$, indicating an insufficient dosage of sodium hypochlorite. Then, its dosage was adjusted in the subsequent analyses. 
Most of the samples referring to $\mathrm{pH}$ lied within limits established by the Ministry of Health. Only the sixth sample was below the lower limit. It is important to emphasise again that the lower and upper limits specified in the ordinance are, respectively, 6.00 and 9.50. Table $\mathrm{A} 3$ in Appendix $\mathrm{B}$ shows that $\mathrm{pH}$ was not significantly influenced by the following independent factors: collection points and collection days. Therefore, there was no significant variation in the $\mathrm{pH}$ parameter in rainwater.

The hardness concentrations also lied within the limit defined by ordinance 2914 of the Ministry of Health [12], which must not exceed $500 \mathrm{mg} / \mathrm{L}$. The hardness concentrations indicate that there is a possibility of using rainwater to wash clothes. Table A4 in Appendix B shows that hardness was not significantly influenced by the collection points and collection days.

There was a significant increase in total dissolved solids from the eighth sample onwards. Therefore, it is necessary to clean the rainwater tank every six months.

Following the first-flush and the disinfection process, it can be concluded that the rainwater could be used to wash clothes.

\subsubsection{Greywater Reuse to Flush Toilets}

The results of the analysis aiming to reuse greywater for flushing toilets can be seen in Figures A7-A9 in Appendix C. Turbidity, $\mathrm{pH}$, thermotolerant coliforms and free residual chlorine were the parameters analysed. The results were compared to the limits established by NBR 15527 [9].

Regarding turbidity, no samples lied within the limit established by NBR 15527 [9]. The high turbidity is related to suspended solids in the greywater, which can be associated with washing powder and other chemicals.

The chemicals in the greywater can also influence $\mathrm{pH}$. The $\mathrm{pH}$ must lie within 6.00 and 9.00 [9]. Although most of the samples lied within limits, some samples were above the upper limit, a fact associated with the basic characteristics given to water by chemical products during the washing of clothes.

NBR 15527 [9] establishes that the coliform count must be less than 200 organisms per $100 \mathrm{~mL}$. No thermotolerant coliforms were found because disinfection was performed. The monitoring of free residual chlorine in the greywater was also carried out. Concentrations of free residual chlorine must be between 0.50 and $2.00 \mathrm{mg} / \mathrm{L}$ [9].

It is important to note that there were relevant variations in concentrations of the parameters because different concentrations of chemical products were used in the washing. Besides disinfection, as done in our work, we also recommend using a filtration system to reduce the concentration of suspended solids and, consequently, turbidity.

\subsection{Financial Analysis}

The financial benefits generated by the installation of the combined rainwater and greywater system were calculated. The financial benefits generated were calculated comparing the monthly water consumption in 2017 to that in 2018.

Figure 11 shows that the water/sewage bill, charged by the water company, varied between $R \$ 84.38$ and $R \$ 136.50$ in 2018 , resulting in a monthly average equal to $R \$ 104.76$. When compared to the 2017 data, the average monetary reduction was equivalent to $\mathrm{R} \$ 90.95$ per month; the reduction varied between $\mathrm{R} \$ 56.12$ and $\mathrm{R} \$ 184.66$. The average reduction represents a percentage reduction equivalent to $45.76 \%$. The monthly percentage reductions ranged from $29.14 \%$ to $68.64 \%$. It is important to highlight that, in twelve months, after the installation of the combined system, $\mathrm{R} \$ 1000.42$ were saved.

The installation of the combined system was divided into the following stages: foundation and structure, pipes installation, installation of gutters, and electrical installation. Table 10 shows the cost of each construction stage, as well as the financial percentages that represent each stage. 

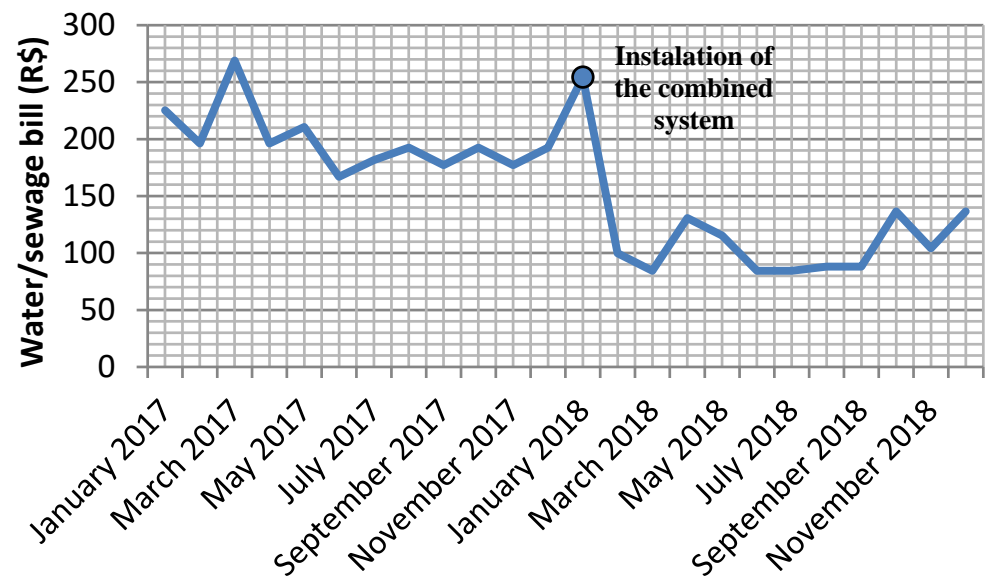

Figure 11. Water/sewage bills before and after installing the combined system.

Table 10. Cost of each construction stage.

\begin{tabular}{ccc}
\hline \multirow{2}{*}{ Stage } & \multicolumn{2}{c}{ Cost } \\
\cline { 2 - 3 } & $\mathbf{( R \$ )}$ & $\mathbf{( \% )}$ \\
\hline Foundation and structure & 302.56 & 7.68 \\
Installation of gutters & 1236.03 & 31.39 \\
Pipes installation & 2052.21 & 52.12 \\
Electrical installation & 346.64 & 8.81 \\
\hline Total costs & 3937.44 & 100.00 \\
\hline
\end{tabular}

The total cost of material for installing the combined system was equivalent to $\mathrm{R} \$ 3937.44$. It was observed that the pipes installation represented the highest percentage due to the acquisition of tanks for rainwater storage and greywater storage. The labour costs were equivalent to $\mathrm{R} \$ 1800.00$. The initial investment was equal to $\mathrm{R} \$ 5737.44$.

When the old water tariff (tariffs charged until February 2020) was considered, the payback period for installing the combined system was equivalent to ten years and seven months. The net present value and the internal rate of return are equal to $\mathrm{R} \$ 3334.14$ and $1.10 \%$ per month, respectively. The new water tariff, implemented in March 2020, in its turn, resulted in a payback period equivalent to eight years and five months. The net present value and the internal rate of return are equal, respectively, to $\mathrm{R} \$ 5211.72$ and $1.35 \%$ per month. Table 11 shows a summary of the results for the financial analysis.

Table 11. Summary of the results for the financial analysis.

\begin{tabular}{ccccc}
\hline Scenario & Initial Investment (R\$) & $\begin{array}{c}\text { Payback Period } \\
\text { (Years) }\end{array}$ & Net present Value (R\$) & $\begin{array}{c}\text { Internal Rate of } \\
\text { Return (\% per Month) }\end{array}$ \\
\hline Old water tariff & 5737.44 & 10.58 & 3334.14 & 1.10 \\
New water tariff & 5737.44 & 8.42 & 5211.72 & 1.35 \\
\hline
\end{tabular}

There are studies that present results similar to the one found in this study. Ghisi and Ferreira [18] obtained payback periods equal to 3.42 and 8 years for two buildings located in the city of Florianópolis. It is important to highlight that the payback period observed was inversely proportional to the potable water savings generated in the building. However, the results are not similar to the one found in the study of [16] in the city of Palhoça, southern Brazil. Payback periods equivalent to 28.17 and 92.67 years were found. However, it is important to note that these values are associated with the flat rate charged by the water company, equivalent to $10 \mathrm{~m}^{3}$ per month. The houses had potable water consumption equal to or less than $10 \mathrm{~m}^{3}$ per month. 
On the other hand, Oviedo-Ocaña et al. [19] obtained a payback period equal to 23 years in a residential complex located in Colombia. The payback period may vary between the different studies carried out because the potable water savings is mainly related to the rainfall characteristics of the region, the rainwater catchment area, tank capacity, and the water tariff.

\section{Conclusions}

The average monthly water consumption after installing the system combining rainwater and greywater was equivalent to $11 \mathrm{~m}^{3}$, representing an average reduction equal to $7 \mathrm{~m}^{3}$. After the installation, an average reduction of potable water consumption equivalent to $38 \%$ was observed.

To ensure safety for users, the rainwater from the catchment area must go through first-flush disposal and a disinfection process. It is necessary to comply with the limits required by the local legislation. Greywater reuse is also possible in the house considered in this study. However, a filtration process and a disinfection process are necessary. It is also important to highlight that the quality analyses are specific to the samples collected in the house of this study. Therefore, for other buildings, new quality studies must be carried out to guaranteeing safety for users.

Although the payback period was not considered short, it is important to note that the study is in line with sustainability because it has reduced the potable water consumption in the house. In 2018, there were potable water savings equivalent to $R \$ 1000.42$ in the water bill. This figure represents a reduction of approximately $46 \%$ when compared to the water/sewage bills for the year 2017.

Based on the new water tariff implemented by the water company, the payback period was equal to eight years and five months, representing a reduction compared to the old water tariff. Although it is not yet considered a short payback, the measure is valid for the rational use of potable water. With the new water tariff, the conscious use of water is more valued, because the bill is directly proportional to the potable water savings.

The results indicated that the combined system can generate a significant reduction in the potable water consumption and that, after passing through the treatment process, rainwater can be used to wash clothes and greywater can be reused to flush toilets. This helps to preserve water bodies and minimise floods in the urban environment. Current studies on rainwater use and greywater reuse are mainly related to non-potable purposes. Therefore, new studies on rainwater use for potable purposes, such as washing clothes, are important for preserving the environment. In this study, it was shown that it is possible to use rainwater for washing clothes, demonstrating that this can be an important alternative for the rational use of water in buildings.

Author Contributions: Conceptualization, G.R. and E.G.; methodology, G.R.; software, G.R.; planning the experiments, G.R.; carrying out the experiments, G.R.; writing — original draft preparation, G.R.; writing - review and editing, E.G.; supervision, E.G. All authors have read and agreed to the published version of the manuscript.

Funding: This research received no external funding.

Institutional Review Board Statement: Not applicable.

Informed Consent Statement: Not applicable.

Data Availability Statement: Data are contained within the article.

Conflicts of Interest: The authors declare no conflict of interest.

\section{Appendix A. Rainwater to Wash Clothes}

Figures A1-A6 show, respectively, the results found for turbidity, apparent colour, free residual chlorine, $\mathrm{pH}$, hardness, and total dissolved solids. The results were compared to the limits established by ordinance 2914 of the Ministry of Health [12] to ensure safety 
for users. The parameters shown in this section were analysed after the first-flush and disinfection process.

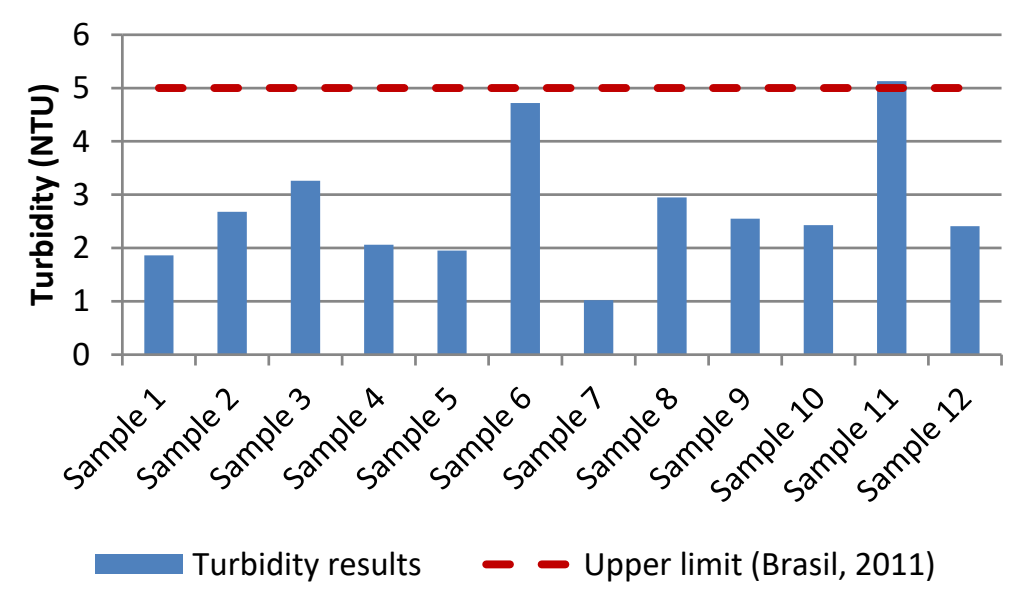

Figure A1. Turbidity of the rainwater after the first-flush and disinfection process.

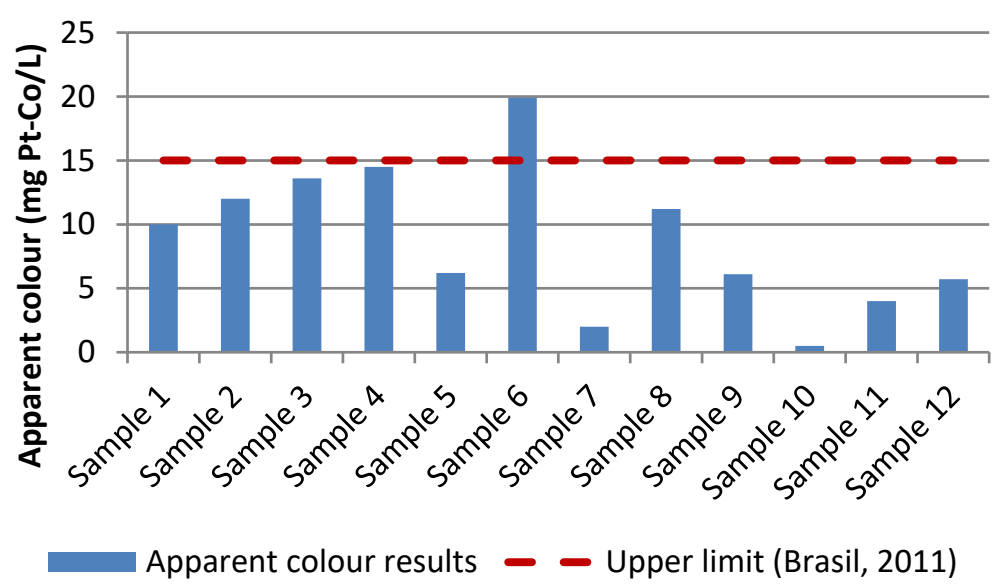

Figure A2. Apparent colour of the rainwater after the first-flush and disinfection process.

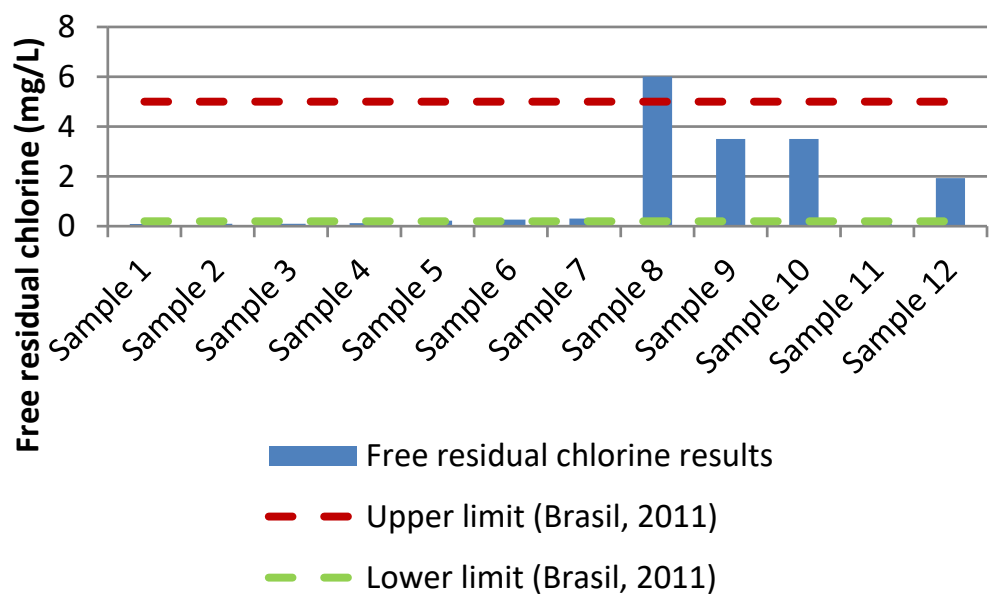

Figure A3. Free residual chlorine in the rainwater after the first-flush and disinfection process. 


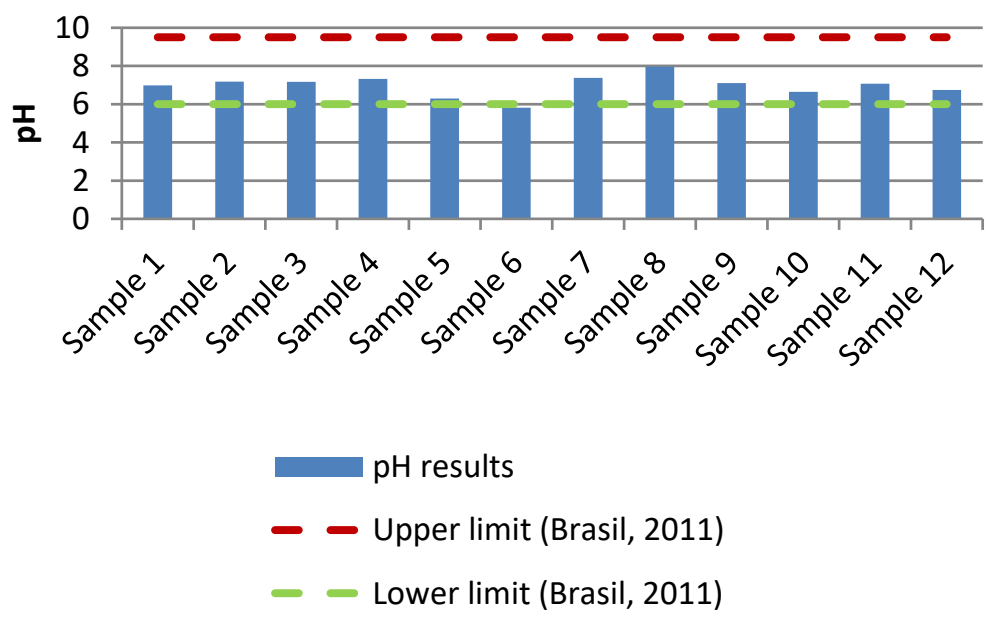

Figure A4. $\mathrm{pH}$ of the rainwater after the first-flush and disinfection process.

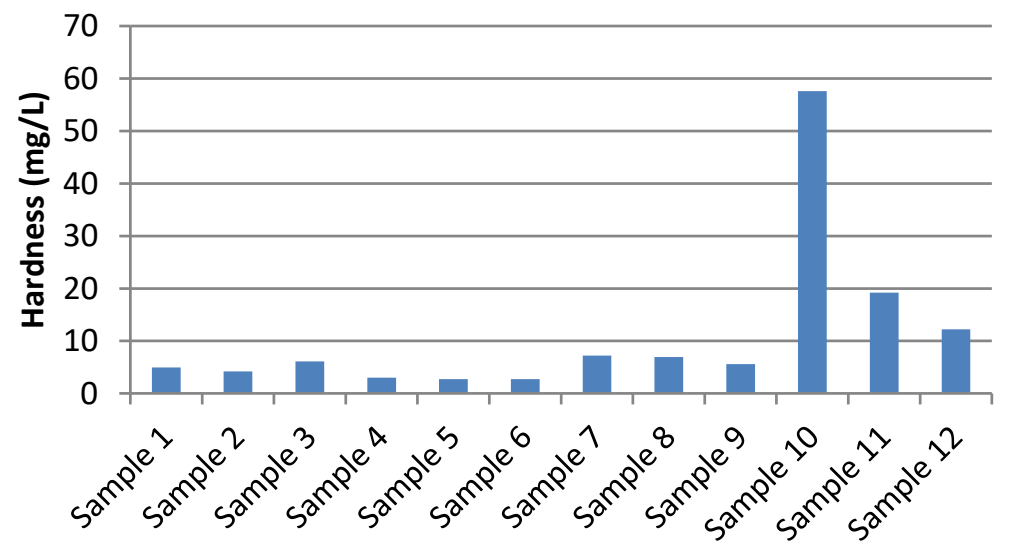

Figure A5. Hardness of the rainwater after the first-flush and disinfection process.

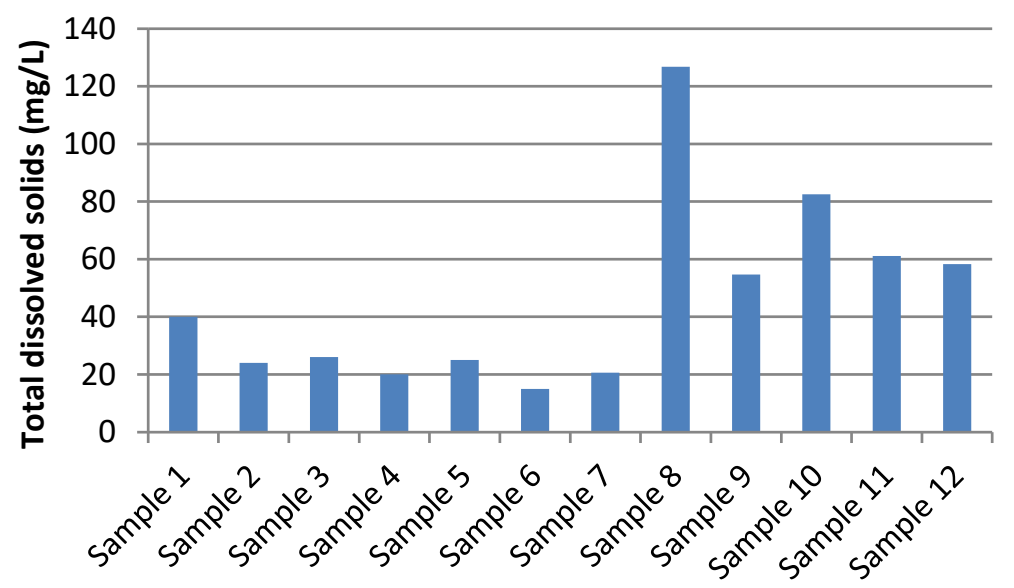

Figure A6. Total dissolved solids in the rainwater after the first-flush and disinfection process.

The thermotolerant coliforms parameter was also analysed. However, it is important to note that no colony-forming units were found.

Appendix B. Rainwater-Statistics for Turbidity, Apparent Colour, pH, and Hardness 
Table A1. Statistics for turbidity.

\begin{tabular}{ccccccc}
\hline Source & Sum of Squares (SS) & $\begin{array}{c}\text { Degrees of } \\
\text { Freedom (DF) }\end{array}$ & Mean Square (MS) & F & Significance Value (p) & Critic F (CF) \\
\hline Regression & 559.85 & 23.00 & $2.25 \times 10^{8}$ & 6.13 & $8.33 \times 10^{-9}$ & -1.71 \\
Residual & 2151.44 & 60.00 & $3.67 \times 10^{7}$ & - & - & - \\
Total & 2711.29 & 83.00 & - & - & - \\
\hline
\end{tabular}

Table A2. Statistics for apparent colour.

\begin{tabular}{ccccccc}
\hline Source & Sum of Squares (SS) & $\begin{array}{c}\text { Degrees of } \\
\text { Freedom (DF) }\end{array}$ & Mean Square (MS) & F & Significance Value $(p)$ & Critic F (CF) \\
\hline Regression & 6919.27 & 9.00 & 768.81 & 2.91 & $1.60 \times 10^{-2}$ \\
Residual & 6873.97 & 26.00 & 264.38 & - & - & -2.27 \\
Total & $13,793.23$ & 35.00 & - & - & - & - \\
\hline
\end{tabular}

Table A3. Statistics for $\mathrm{pH}$.

\begin{tabular}{ccccccc}
\hline Source & Sum of Squares (SS) & $\begin{array}{c}\text { Degrees of } \\
\text { Freedom (DF) }\end{array}$ & Mean Square (MS) & F & Significance Value ( $p$ ) & Critic F (CF) \\
\hline Regression & 0.36 & 5.00 & 0.07 & 0.31 & 0.90 & - \\
Residual & 4.23 & 18.00 & 0.23 & - & - & - \\
Total & 4.59 & 23.00 & - & - & - \\
\hline
\end{tabular}

Table A4. Statistics for hardness.

\begin{tabular}{ccccccc}
\hline Source & Sum of Squares (SS) & $\begin{array}{c}\text { Degrees of } \\
\text { Freedom (DF) }\end{array}$ & Mean Square (MS) & F & Significance Value ( $p$ ) & Critic F (CF) \\
\hline Regression & 0.38 & 5.00 & 0.08 & 0.0004 & 1.00 & -2.77 \\
Residual & 3290.65 & 18.00 & 182.81 & - & - & - \\
Total & 3291.03 & 23.00 & - & - & - \\
\hline
\end{tabular}

\section{Appendix C. Greywater Reuse to Flush Toilets}

Figures A7-A9 show, respectively, the results for turbidity, $\mathrm{pH}$, and free residual chlorine. The results were compared to the limits established by NBR 15527 to ensure safety for users [9].

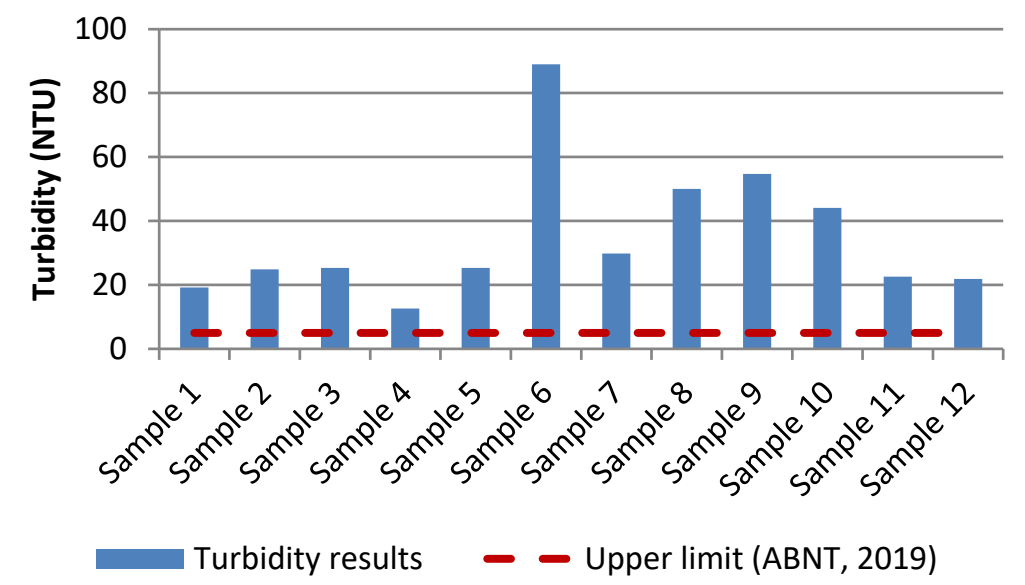

Figure A7. Turbidity of the greywater to flush toilets. 


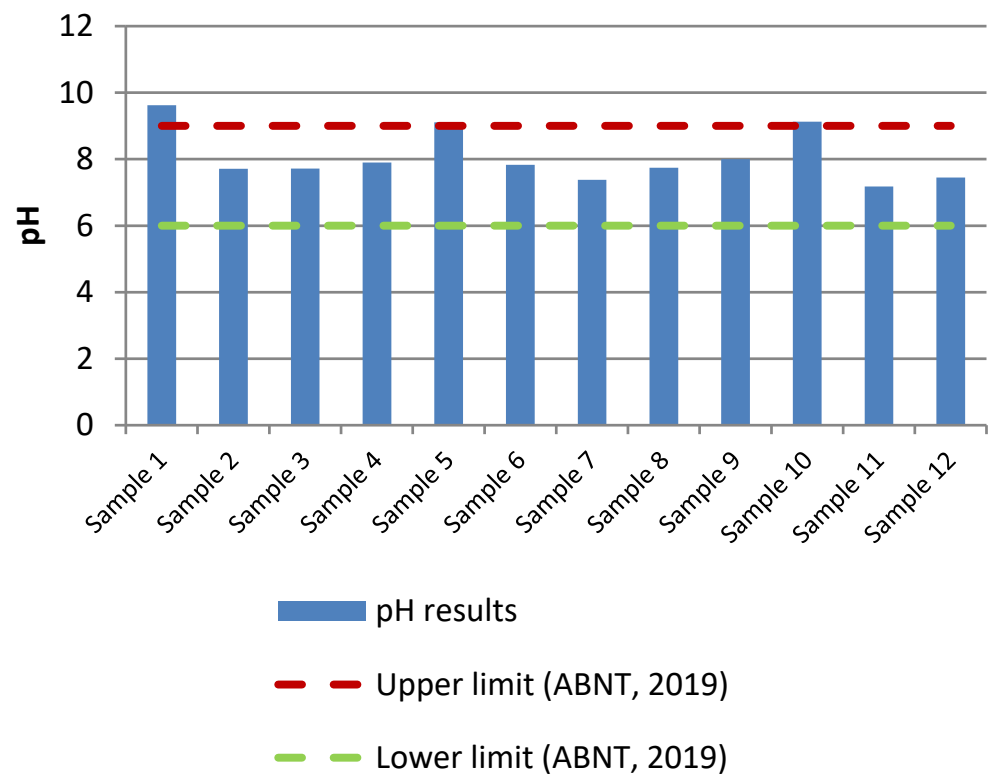

Figure A8. $\mathrm{pH}$ of the greywater to flush toilets.

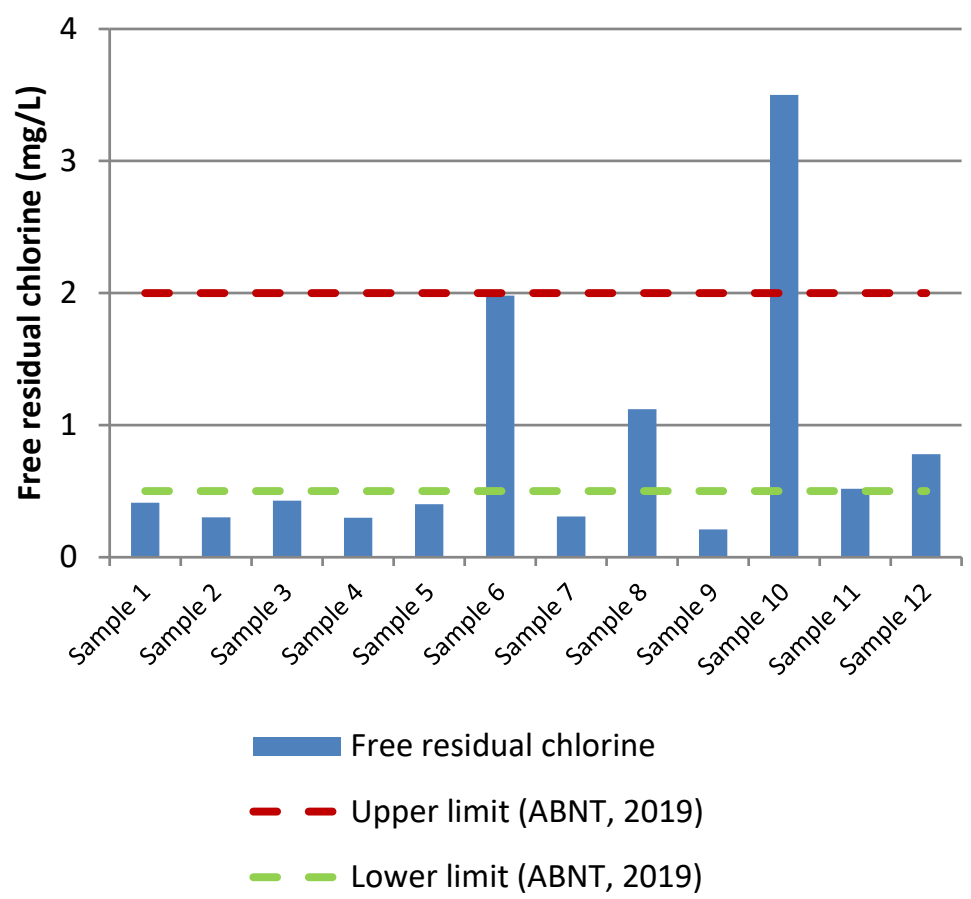

Figure A9. Free residual chlorine in the greywater to flush toilets.

The thermotolerant coliforms parameter was also analysed. However, no colonyforming units were found.

\section{References}

1. Lee, M.; Kim, M.; Kim, Y.; Han, M. Consideration of rainwater quality parameters for drinking purposes: A case study in rural Vietnam. J. Environ. Manag. 2017, 200, 400-406. [CrossRef] [PubMed]

2. Fernandes, L.F.S.; Terêncio, D.P.; Pacheco, F.A.L. Rainwater harvesting systems for low demanding applications. Sci. Total. Environ. 2015, 529, 91-100. [CrossRef] [PubMed]

3. Leong, J.Y.C.; Oh, K.S.; Poh, P.E.; Chong, M.N. Prospects of hybrid rainwater-greywater decentralised system for water recycling and reuse: A review. J. Clean. Prod. 2017, 142, 3014-3027. [CrossRef] 
4. Loux, J.; Winer-Skonovd, R.; Gellerman, E. Evaluation of Combined Rainwater and Greywater Systems for Multiple Devel-opment Types in Mediterranean climates. J. Water Sustain. 2012, 2, 55-77.

5. Akter, A.; Ahmed, S. Potentiality of rainwater harvesting for an urban community in Bangladesh. J. Hydrol. 2015, 528, 84-93. [CrossRef]

6. Domènech, L.; Saurí, D. A comparative appraisal of the use of rainwater harvesting in single and multi-family buildings of the Metropolitan Area of Barcelona (Spain): Social experience, drinking water savings and economic costs. J. Clean. Prod. 2011, 19, 598-608. [CrossRef]

7. Johnson, K.; Loux, J. Water and Land Use: Planning Wisely for the Future of California; Solano Press Books: Point Arena, CA, USA, 2014.

8. Brasil. Lei Federal no 9433 de 8 de Janeiro de 1997. Institui a Política Nacional de Recursos Hídricos, Cria o Sistema Nacional de Gerenciamento de Recursos Hídricos, Regulamenta o Inciso XIX do Art. 21 da Constituição Federal, e Altera o Art. 1o da Lei no 8001, de 13 de Março de 1990, Que Modificou a Lei no 7990, de 28 de Dezembro de 1989. 1997. Available online: http:/ / www.planalto.gov.br/ccivil_03/leis/L9433.htm (accessed on 17 August 2017). (In Portuguese)

9. ABNT (Associação Brasileira de Normas Técnicas). Água de chuva-Aproveitamento de Coberturas em Áreas Urbanas Para Fins não Potáveis-Requisitos [Rainwater-Harvesting from Roofs in Urban Areas for Non-Potable Uses-Requirements]; NBR 15527; ABNT: Rio de Janeiro, Brazil, 2019. (In Portuguese)

10. Ghisi, E.; Cordova, M.M. Netuno 4-Manual do Usuário. Laboratory of Energy Efficiency in Buildings. 2014. Available online: http:/ / www.labeee.ufsc.br/sites/default/files/Manual-Netuno-4_Junho2014.pdf (accessed on 27 July 2017). (In Portuguese).

11. Cordova, M.M.; Ghisi, E. Analysis of Potable Water Savings Using Behavioural Models. In Water Con-Servation, 1st ed.; Manoj, K., Ed.; InTech Open: Rijeka, Croatia, 2011; pp. 89-104.

12. Brasil. Portaria no 2914, de 12 de Dezembro de 2011. Dispõe Sobre Normas de Potabilidade de Água Para o Consumo Humano. 2011. Available online: http://bvsms.saude.gov.br/bvs/saudelegis/gm/2011/prt2914_12_12_2011.html (accessed on 1 July 2019). (In Portuguese)

13. APHA; AWWA; WEF. Standard Methods for the Examination of Water and Wastewater, 22nd ed.; American Public Health Association: Washington, DC, USA, 2012.

14. Rosa, G.C. Análise Quali-Quantitiva e Econônica de um Sistema Combinado de Aproveitamento de Água Pluvial e Reúso de Água Cinza em uma Residência Unifamiliar. Master's Thesis, Federal University of Santa Catarina, Florianópolis, Brazil, 2019. (In Portuguese).

15. Muthukumaran, S.; Baskaran, K.; Sexton, N. Quantification of potable water savings by residential water conservation and reuse-A case study. Resour. Conserv. Recycl. 2011, 55, 945-952. [CrossRef]

16. Ghisi, E.; De Oliveira, S.M. Potential for potable water savings by combining the use of rainwater and greywater in houses in southern Brazil. Build. Environ. 2007, 42, 1731-1742. [CrossRef]

17. Marinoski, A.K.; Rupp, R.F.; Ghisi, E. Environmental benefit analysis of strategies for potable water savings in residential buildings. J. Environ. Manag. 2018, 206, 28-39. [CrossRef]

18. Ghisi, E.; Ferreira, D.F. Potential for potable water savings by using rainwater and greywater in a multi-storey residential building in southern Brazil. Build. Environ. 2007, 42, 2512-2522. [CrossRef]

19. Oviedo-Ocaña, E.R.; Dominguez, I.; Ward, S.; Rivera-Sanchez, M.L.; Zaraza-Peña, J.M. Financial feasibility of end-user designed rainwater harvesting and greywater reuse systems for high water use households. Environ. Sci. Pollut. Res. 2018, 25, 19200-19216. [CrossRef] [PubMed]

20. SNIS (Sistema Nacional de Informações sobre Saneamento). Diagnóstico dos Serviços de Água e Esgotos. Ministério das Cidades. 2015. Available online: www.snis.gov.br (accessed on 10 February 2017). (In Portuguese)

21. Von Sperling, M. Introdução à Qualidade das Águas e ao Tratamento de Esgotos, 4th ed.; Editora UFMG: Belo Horizonte, Brazil, 2014. (In Portuguese) 